\title{
Animal experimentation and scientific knowledge: a thought style?
}

\author{
Thales de Astrogildo e Tréz*
}

Institute of Human Sciences, Federal University of Alfenas

\begin{abstract}
Animal experimentation, besides a research method extensively applied in the production of scientific knowledge, is also considered essential to science and with undeniable historical relevance in advances in human health. In this survey, a questionnaire was applied to a group of researchers involved with research based on non-animal models $(\mathrm{n}=18)$, and to another group involved with research based on animal models $(\mathrm{n}=18)$. The data analysis was grounded in Ludwik Fleck (1896 -1961) epistemological assumptions. The results suggested that there are at least two thought styles operating in consonance on the same research problem (advances in human health conditions) with significantly different conceptions not only concerning the research practices involved, but also the historical conceptions related to the role of animal experimentation.
\end{abstract}

Uniterms: Animal experimentation. Ludwik Fleck. Science/public understanding. Epistemology. Research methodology.

A experimentação animal, além de método amplamente aplicado na produção do conhecimento científico, é considerada como essencial à ciência e com valor histórico inegável no progresso das condições de saúde humana. Neste levantamento, um questionário foi aplicado a um grupo de pesquisadores com trabalhos baseados em modelos não-animais $(n=18)$ e a outro grupo com trabalhos baseados em modelos animais $(\mathrm{n}=18)$. A análise de dados se baseou nos pressupostos epitemológicos de Ludwik Fleck (1896-1961). Os dados sugerem que existem pelo menos dois estilos de pensamento operando em consonância sobre o mesmo problema de pesquisa (avanços nas condições de saúde humana), com concepções significativamente diferentes sobre as práticas de pesquisa envolvidas, assim como as concepções históricas relacionadas ao papel da experimentação animal.

Unitermos: Experimentação animal. Ludwik Fleck. Ciência/entendimento publico. Epistemologia. Metodologia de pesquisa.

\section{INTRODUCTION}

The practice of animal experimentation in the scientific and academic field is common (Lima, 2008). Its trajectory goes back centuries in the history of humanity and its historical establishment as a practice in science is well described in the literature (see French, 1999).

Animal research is considered by many to be fundamental for science, and primarily responsible for advances in human and animal health (Petroianu, 1996; Andrade et al. 2002; Guerra, 2004; Marques et al., 2005; Lima, 2008; Morales, 2008; d'Acampora et al., 2009). According to Marques et al. (2009) "virtually every

*Correspondence: T. A. Tréz. Instituto.de Ciências Humanas, Universidade Federal de Alfenas. Rua Gabriel Monteiro da Silva, 700, 37130-000 - Alfenas - MG, Brasil. E-mail: thales.trez@unifal-mg.edu.br advance in human and veterinary medicine has been obtained through animal research". "The benefits achieved with the use of animals in research are undeniable," and "largely, the results of animal experiments justify its use in research" (Rezende et al., 2008). In an article published in the newspaper Folha de São Paulo, the president of the Federation of Societies for Experimental Biology (FESBE), before concluding that the use of animals in science is absolutely necessary, makes the following comparison:

The use of animals is so basic to science as is the act of breathing for anyone of us. To explain it in another way, the interruption of animal experimentation would represent death to an important part of science, humans and the planet (Mello, 2007, p.3). 
And Morales points out (2008):

To what extent society is willing to give up the use of animals in research with the risk of blocking the advancement of biological knowledge, testing and development of new drugs, vaccines and surgical methods? (p.33)

Similarly, Guerra (2004), implicitly taking the view that animal research is a synonym for scientific activity, reiterated that animal experimentation is responsible for vaccines, antibiotics, surgical knowledge, etc., and is linked to discoveries of great social impact and increased longevity. Lima (2008) agrees:

the immediate consequence of progress determined by the use of animals in science is attested by the increase in the twentieth century, of approximately 23.5 years in life expectancy of populations. (p. 26, emphasis added)

Generally speaking, both in Brazil and worldwide, there seems to be a favorable (and possibly hegemonic) stance by the scientific community regarding the use of animal models in research activities, supported in Brazil by a united and deep-rooted discourse. It is believed that the animal model is a biological reagent able to predict with considerable confidence, the effects of certain substances or interventions when subsequently applied to humans. This confidence is increased by genetic manipulation, thereby making the animal model supposedly even more faithful to the expected response in the human body. There are now appropriate animal models for each type of experiment, which enables further universalization of the methods for animal research (Andrade et al., 2002).

This apparent movement of harmony in relation to animal use in research seems to be accompanied by an increasingly more emphatic discourse in relation to the method in subject, as we observed in Markus (2008): "the importance of animal experimentation for the progress of knowledge is undeniable". In fact, expressions such as "undeniable", "indispensable", "fundamental", "unquestionable" and "necessary" are commonly found in animal experimentation defenses and justifications, most likely in response to the growing controversy and problematization of these practices that began some 3 decades ago with the emergence of the animal defense and rights movement.

The discourse against the use of animals is also frequently seen as anti-scientific (see Petroianu, 1996). Guerra (2004), in relation to the lay persons with a poor understanding of scientific progress and the importance of science, affirmed:
The rejection of the methods of scientific research doesn't just reveal love for animals, but also an aversion to scientific knowledge (science phobia) or to technological progress (technophobia) (p. 99)

Also, legislations that threaten experimental practices with animals are deemed harmful or obstructive to scientific and technological progress (see Schnaider, Souza, 2003). This was the case for the municipal laws that intended to abolish animal experimentation in the cities of Rio de Janeiro and Florianópolis, in 2006 and 2007 , respectively.

\section{Ludwik Fleck's socio-genesis of knowledge contribution}

The book Genesis and Development of a Scientific Fact by microbiologist and Polish epistemologist Ludwik Fleck (1896-1961) is an epic on the development of scientific thought and practice, from which Thomas Kuhn drew strong inspiration for his work The structure of scientific revolutions. Fleck's pioneering approach is attributed to the fact that "his epistemological work is dedicated to the medicine field, which possesses particularities not found in other extents" (Pfuetzenreiter, 2002).

Fleck proposes the idea of thought styles (TS) to understand the practices and shared historical knowledge of different collectives, including the scientific community. According to Fleck (1986), the TS is a "driven perception with the correspondent intellectual and objective elaboration of the noticed".

The style is characterized by the problems the collective are interested in, for the judgments that the collective thought considers evident, and for the methods used as a means of gaining knowledge. Besides, it provides coercion on the individuals, determining what cannot be thought of in another way (Nascimento, 2005, p. 3).

The TS is then the basis for the thought collective (TC). According to Schafer \& Schnelle (1986), if the TS contain the shared presuppositions on which the collective builds its theoretical and practical framework, the TC is the social unit of a community of a certain field (in this case, of scientists). When considering animal experimentation as a consolidated scientific practice, its own TS can be suggested, sustained by a TC interested in the maintenance of this practice. In this maintenance, the concept of thought coercion can be important in the analysis of this phenomenon, since it concerns the instruction of different 
scientific collectives, more as indoctrination than an incentive to critical-scientific thought. According to Fleck (1986), "all didactic introduction is, therefore, literally, a 'drive inside' or a soft coercion". Thought coercion is responsible for the harmony of the illusions - an existent consensus in the system of ideas within the TS, "adapting the subject to the knowledge consolidated by the thought style" (Queirós, Nardi, 2008). During this harmony, there is the period that Fleck calls classic, where there is the extension of the TS, and the moment of complication. According to Delizoicov et al. (2002), "in the first, there is the observation of facts that perfectly fit in the dominant theory. On the second [moment], they become conscious to the exceptions". The complication in Fleck is similar to what Thomas Kuhn denominates anomaly.

The anomaly in the Kuhnian perspective is related to the problems that the effective paradigm is unable to explain and results in a crisis in the study area. Similarly, Fleckian complications are associated to limitations of the thought style to face certain problem (Gonçalves et al., 2007. p. 6).

\section{OBJECTIVES}

General: To identify the possibility of two thought collectives in the scientific community in relation to animal modeling in scientific research activities, both concerned with the problem of safety of techniques and drugs for human beings.

Specific: To identify the positioning of two different research groups in relation to the employment of animal models in scientific research activities and to compare the degree of disagreement/agreement between two research groups.

\section{METHODOLOGICAL DESIGN}

The methodology can be framed as a traverse crosssectional survey guided by descriptive - exploratory and analytical-quantitative character. A non-probabilistic sampling, case-critical type, was used, where participants were chosen because they represent essential cases for the focus of the research (Freitas et al., 2000).

A questionnaire was devised containing 12 questions on a Likert scale, one multiple choice question, and an optional field for comments. This questionnaire was made available online in Portuguese and English. The total 13 questions were:

\section{(Likert Scale)}

1. Human based models are the best way to achieve effective results to problems related to human health.

2. Technologies applied in research will not be capable of replacing animals.

3. To abandon animal modeling in research will cause serious delays in discovering new drugs and therapies, both for human and animals.

4. It is an exaggeration to consider animal experimentation as the main factor responsible for advances in human health.

5. It is ethically unjustifiable to use animals for educational purposes.

6. It is not possible to replace animals in some educational practices.

7. Ethical problems raised by animal experimentation can be overcome by the positive impact animal experimentation cause on human and animal health.

8. Scientific research could replace all animal use, in the medium term, if substantial financial resources were dedicated to the development of non-animal research techniques.

9. In general, animals are not good models for human beings in human health research.

10. Results coming from animal experimentation are doubtful and misleading with regard to their effect on human beings.

11. Tradition in science is the main force that makes animal experimentation the rule nowadays.

12. Animal experimentation is essential to science.

(Multiple choice)

13. Please choose the option that best represents your opinion:

(A) "I believe that there are better methods for research on human and animal health issues than animal experimentation. I'm actively working in research to replace animals in some experiments in my field of investigation".

(B) "Animal experimentation is a necessity for most current research. Its importance is undeniable and it has been responsible for most advances in human and animal health care".

(C) "I don't think scientific research will ever abandon all animal use, independently of my agreement or disagreement on this issue".

(D) "I agree that new technologies might replace animal model in human and animal health research, and I fully understand why this should happen, but my field of research demands the employment of animal as models".

(E) None. 
To establish relationships among the questions in the present research, Pearson's correlation coefficient was applied (the correlation was considered strong when $\mathrm{p}>0.8$ ). A strong correlation indicates that the answers were distributed in a very similar way (amongst entries for Likert Scale categories).

The study participants were researchers with recent publications in qualified scientific events or magazines. Through intentional sampling, two groups were defined: Group (A) with research based on non-animal models, and Group (B) with research based on animal models. The contact with researchers of Group A was made during the VII World Congress on Alternatives \& Animal Uses in the Life Sciences ${ }^{1}$, by identifying the main researchers of each presented work on the posters. The contact with researchers of Group B was made through Scielo (Scientific Electronic On-line Library), in searches for articles published recently and that made explicit reference to the use of animal models in their titles, in the following journals: Brazilian Surgical Acta, Nutrition Magazine, Brazilian Magazine of Otorhinolaryngology and Brazilian Journal of Microbiology ${ }^{2}$. An invitation to participate in this research, together with its description, was sent by email to researchers of both groups, with a deadline for answering. Two other emails were sent close to the deadline as reminders. A randomly generated code was sent to each researcher (e.g. Y2R, WLC5), to identify the questionnaires soon after they were answered (through mailed forms) while avoiding disclosure of both the respondents name (or email) identification, as well as possible duplicates or external interferences, since the questionnaires were made available online with unrestricted access.

In the data organization, criteria for the answers were established as either innovative or traditional. "Innovative" is understood in this survey as the most critical entries to the application of animal modeling in research, and "traditional" the entries in harmony with this model.

Akin to the Likert scale there are options for agreement (A)/strong agreement (AA) and disagreement (D)/ strong disagreement (DD), some answers were grouped considering the entries at these different degrees of (A) and (D). Thus, in data where (AA) or (DD) represented at least $50 \%$ of (A) or (D), respectively, there is indication of a strong emphasis in the predominance of the answers. For instance:

\begin{tabular}{|c|c|c|c|c|}
\hline Q11 & SA & A & D & SD \\
\hline & 0 & 5 & 6 & 4 \\
\hline
\end{tabular}

In the example above, the disagreement is considered with strong emphasis, because (DD) represents more than half of (D). In the discussion, strong agreement will be represented as AA, weak agreement as A, strong disagreement as DD and weak disagreement as D. In distributions smaller than $50 \%$, the agreement or disagreement is considered as "moderate" or "slight".

\section{RESULTS}

Responsivity in the present research is shown in Table I.

TABLE I - Response chart

\begin{tabular}{lccc}
\hline & Contacted & Answers & $\%$ \\
\hline Group A & 93 & 18 & 19.4 \\
Group B & 75 & 18 & 24 \\
\hline Total & 168 & 36 & 21.4 \\
\hline
\end{tabular}

Figure 1 depicts the behavior of both groups in relation to the answers for the first 12 questions. An initial consideration can be inferred based on the fact that the innovative entries of group A are higher than group $B$ innovative entries across all questions, i.e. $\mathrm{P}(\mathrm{A})>\mathrm{P}(\mathrm{B})$. The traditional entries show the opposite pattern between the groups: $\mathrm{T}(\mathrm{A})<\mathrm{T}(\mathrm{B})$.

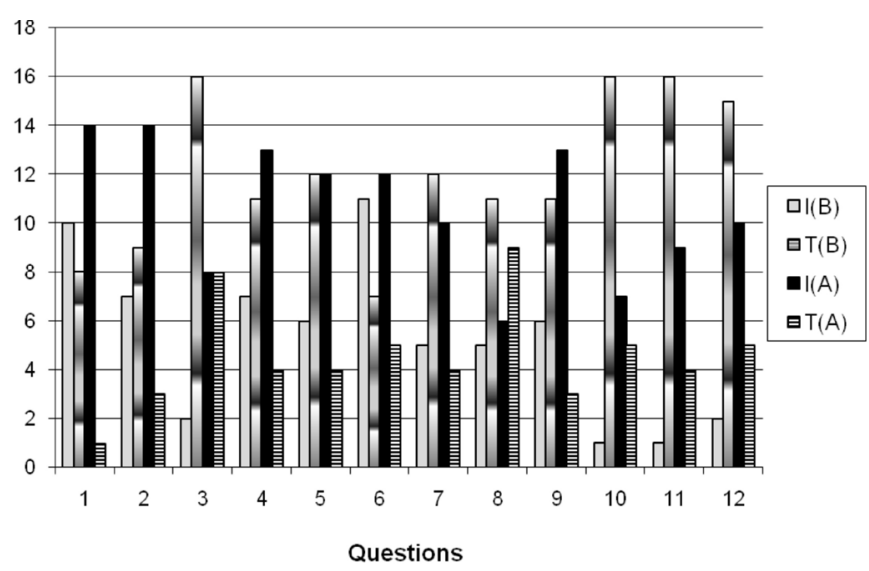

FIGURE 1 - Distribution of answers in Groups A and B. The horizontal axis represents the questions, and the vertical axis, the entries. Legend: $\mathrm{I}(\mathrm{A})$ and $\mathrm{T}(\mathrm{A})$ indicate innovative and traditional entries of Group A, respectively; I(B) and T(B) innovative and traditional entries of Group B, respectively.

\footnotetext{
${ }^{1}$ This congress took place in Rome (Italy) from August 30 to September 3, 2009. The studies were published in the magazine Alternatives to Laboratory Animals (ATLA) - Eigenfactor 2007: 0.0012344 / ISI impact factor: 3.014.

${ }^{2}$ Qualis national B (Brazilian national ranking).
} 


\section{Initial considerations of the study instrument}

The number of entries for the option "Neither agree nor disagree" (NAND) was higher in Group A (average of $15 \%$ of total entries) than in Group B (average of $4 \%$ of total entries), but nevertheless considered small. One comment received from Group A (Chart 1, comment A4) expressed lack of the option "It depends". In fact, NAND entries might have been applied with this sense by both groups, but this does not invalidate the other positions identified in each of the questions. There will be an indication where NAND entries are considered more frequent $(<20 \%)$ in the analysis of each question.

\section{Questions}

Question 1 - "Human based models are the best way to achieve effective results to problems related to human health" - agreement is considered innovative in this question, since it recognizes modeling in research as more efficient if based on human beings, and not on animals, when research is dealing with human health. Agreement on this statement for Groups A and B represented 77.8\% and $55.6 \%$ of responses, respectively. Group A thus showed significantly higher agreement than Group B ${ }^{3}$. Disagreement was greater in Group B (40\%, with emphasis) in relation to Group A (5.6\%) suggesting a more positive position overall in Group A.

Question 2 - "Technologies applied in research will not be capable of replacing animals" - agreement here is considered traditional, because it indicates a disbelief in new technologies as an innovation factor in research as well as in promoting scientific knowledge. Group A 77.8\% disagreed, while Group B 50\% agreed (with 38.9\% disagreement) - both with strong emphasis ${ }^{4}$.

Question 3 - "To abandon animal modeling in research will cause serious delays in discovering new drugs and therapies, both for humans and animals" - agreement on this question is considered traditional, since it deems animal experimentation critically indispensable in developing drugs and therapies, whereas disagreement is viewed as positive, since it suggests faith in new approaches and technologies that could guarantee this development. The positioning among groups was again different. In group B, the agreement/disagreement relationship was $88.9 \%$ and $11.1 \%$, respectively with strong emphasis on agreement $(\mathrm{AA}=9 / \mathrm{A}=7)$. In Group $\mathrm{A}$ this relationship was equal at $44.4 \%$. The behavior in Group A can be considered more moderate on its positioning in relation to the emphatically positioned Group B.

Question 4 - "It is an exaggeration to consider animal experimentation as the main factor responsible for advances in human health" - agreement on this sentence is considered innovative, since it considers other factors as essential to progress in medicine and in human health conditions. The observed positioning between groups was antagonistic on this question. In Group B, the agreement/ disagreement relationship was $381.9 \%$ and $61.1 \%$, respectively, with strong emphasis on disagreement $(\mathrm{DD}=5$ / $\mathrm{D}=6$ ). In Group $\mathrm{A}$, the same relationship was $72.2 \%$ and $22.2 \%$, with slight emphasis in agreement $(\mathrm{AA}=4 / \mathrm{A}=9)$.

Question 5 - "It is ethically unjustifiable to use animals for educational purposes" - agreement with this statement was considered innovative, because it moves forward under contemporary ethical considerations, taking into account the particularity of didactic animal use. Also, the positioning between the groups is antagonistic. In Group B, 33.3\% agreed with the statement versus $66.7 \%$ in disagreement (with significant emphasis: $\mathrm{DD}=5 / \mathrm{D}=7$ ). For Group A, 22.2\% disagreed, compared with $66.7 \%$ emphatically concordant $(\mathrm{AA}=7 / \mathrm{P}=5)$.

Question 6 - "It is not possible to replace animals in some educational practices" - disagreement with this statement was considered innovative, because it accompanies a world tendency that is observed in different universities in many countries, including Brazil. Both groups disagreed with the statement. In Group B the disagreement was $61.1 \%$, and $66.7 \%$ in Group A, with slight emphasis for both groups.

Question 7 - "Ethical problems raised by animal experimentation can be overcome by the positive impact animal experimentation causes on human and animal health" - disagreement with this statement is taken as innovative, because it signals a more cautious posture in relation to the treatment that one should give to the complex scenarios that are involved in situations of ethical conflict. This statement was viewed antagonistically by the groups. Group B had $66.7 \%$ agreement, with strong emphasis $(\mathrm{AA}=5 / \mathrm{A}=7)$, while Group A 55.6\% disagreement, with moderate emphasis. The rate of NAND answers was more accentuated in Group A, representing 22.2\%.

Question 8 - "Scientific research could replace all animal use, in the medium term, considering substantial financial resources dedicated to the development of nonanimal research techniques" - there was a tie among the groups on this question. Both seem to weakly disagree 
with the statement. Disagreement in Group A was 50\%, and $61.1 \%$ in Group B. Agreement is practically equal between the groups at $33.3 \%$ and $27.8 \%$, respectively. One comment received from Group A (Chart 1, comment A3) criticized the lack of precision with the expression "medium term", exposing a problem in the wording of the sentence, and compromising the data gathered for this question.

Question 9 - "In general, animals are not good models for human beings in human health research"- agreement here is considered innovative, because it assumes a critical point of view to a statement that seems to be the base argument for experimental research with animals. The positioning is antagonistic between the groups. In Group B, 61.1\% disagree with strong emphasis ( $\mathrm{DD}=4 /$ $\mathrm{D}=7$ ), while in Group A around $72 \%$ agrees with moderate emphasis 5 . In Group B the agreement rate was 33.3\% versus $16.7 \%$ discordant in Group A.

Question 10 - "Results coming from animal experimentation are doubtful and misleading with regard to effects on human beings" - as in the previous statement, the agreement is considered innovative, and suggests what question 1 emphasized as the best model on research into human health. A different positioning is observed by the two groups on this other important statement. Almost $89 \%$ of Group B indicated disagreement with moderate emphasis versus $38.9 \%$ agreement in Group A, also with moderate emphasis ${ }^{6}$. The nuance in Group A however is notable: $27.8 \%$ disagreement, and $33.3 \%$ NAND.

Question 11 - "Tradition in science is the main force that makes animal experimentation the rule nowadays" - agreement is considered innovative, because it recognizes various elements (including culture) in the scientific enterprise that operate in the maintenance and conservation of practices and concepts that characterize science, assuming a critical point of view about animal experimentation. The positioning here is antagonistic between the groups. Almost 89\% in Group B disagreed with the statement with strong emphasis, versus $50 \%$ agreement in Group A, also with strong emphasis ${ }^{7}$. The nuance in Group A again needs highlighting: $22.2 \%$ disagreement, and $27.8 \%$ NAND.

Question 12 - "Animal experimentation is essential to science" - disagreement is considered innovative since it recognizes the diversity of experimental models found and already applied in scientific research. The positioning is antagonistic between the groups. In Group B, the agree- ment represents $83.3 \%$ with strong emphasis. In Group A, disagreement represents $55.6 \%$, also with strong emphasis, versus $27.8 \%$ agreement $^{8}$.

Question 13: the pattern of distribution of offered options was more solid in Group A than in B (Figure 2). Option A was most selected by Group A (72.2\%), whereas in Group B, the most selected options were B (33.3\%) and D $(33.3 \%)$.

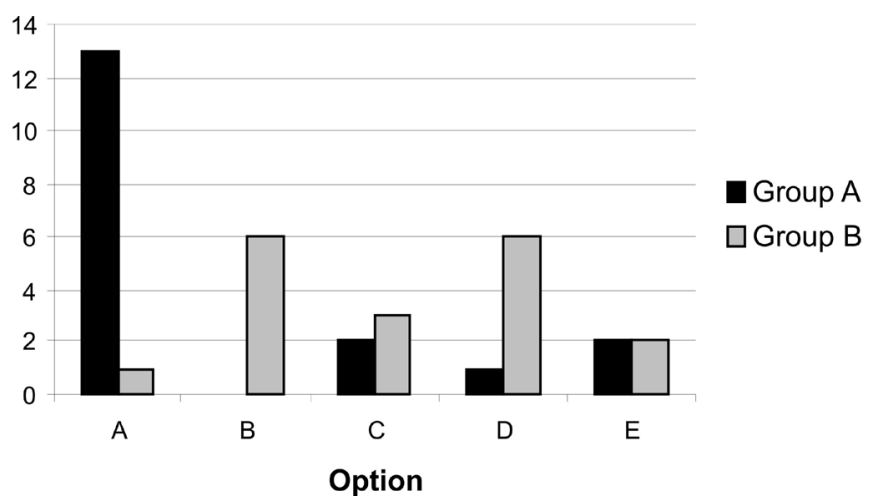

FIGURE 2 - Distribution of answers on question 13 for both groups.

In Group A, the most selected option (A) affirmed: "I believe that there are better methods for research on human and animal health issues than animal experimentation. I'm actively working in research to replace animals in some experiments in my field of investigation". This statement not only suggests a critical perspective in relation to animal experimentation, but engagement with other research methods.

In Group B, option B affirmed: “Animal experimentation is a necessity for most current research. Its importance is undeniable and it has been responsible for most advances in human and animal health care". The explicit stance in this statement is the traditional perspective, sustaining the discourses favoring animal experimentation through a specific historical interpretation of scientific knowledge development, and does not seem open to discussing the importance of this procedure, naturalizing it. Option D affirmed: "I agree that new technologies might replace animal models in human and animal health research, and I fully understand why this should happen, but my field of research demand the employment of animal as models". This statement, considered less conservative than B, takes account of the forces that operate in research fields and, consequently, in research behaviors. 


\section{Correlation between the groups}

The analysis through Pearson's coefficient sought to correlate the questions with similar patterns of answers within and between the two groups. In Group A, 11 questions were strongly correlated ${ }^{9}$ versus 9 in Group $\mathrm{B}^{10}$. There was a strong correlation in questions 4-9 and 6-8 between Groups A and B. Because a bad formulation was identified for Question 8's statement, this last correlation was disconsidered. For Group A, the correlation among Questions 4 and 9 occurs in terms of agreement to the sentences, yet in disagreement for Group B. These questions are considered crucial in the subject of research with animals, and the strong correlation demonstrated among these questions, for both groups, suggests a positioning considered relevant for this research.

\section{Received comments}

The questionnaire offered an optional box for comments (Chart 1). Four comments were received from each group. In group B, in spite of the traditional point of view (B2 and B3) found in relation to animal models applied in research, comments were made that diverge from the tendency observed in Group B, such as in B1: "I believe the time will come when the use of animals will be reduced or abolished", and B4: "There is an excess of animal research with doubtful scientific value (...). I think there is a lot of animal sacrifice for little benefit".

In Group A, the comments were more moderate. Comments A1, A2 and A 3 could be construed as recognizing the value of replacement methods, but they do not deny the importance, clearly circumstantial, of animal ex-

CHART 1 - Spontaneous comments received by respondents of each group

\begin{tabular}{|c|c|}
\hline Group A & Group B \\
\hline $\begin{array}{l}\text { (A1) Non-animal and animal testing should go hand in hand with the purpose } \\
\text { of phasing out animal testing. Good luck with the survey. }\end{array}$ & $\begin{array}{l}\text { (B1) In my point of view, we are going through } \\
\text { a period in which studies with animals are } \\
\text { essential for the evolution of medicine. I believe } \\
\text { the time will come when the use of animals will } \\
\text { be reduced or abolished }\end{array}$ \\
\hline $\begin{array}{l}\text { (A2) Many in vitro tests are being developed now to replace or reduce } \\
\text { animal experimentation. A single in vitro test is not able to predict an effect } \\
\text { in animals but batteries of in vitro tests are necessary and even then are not } \\
\text { enough to be successful. In vitro tests are static tests, the use of an entire } \\
\text { organism integrates the notion of the dynamic absolutely necessary for } \\
\text { obtaining reliable pharmacokinetics data. Currently, these in vitro tests are } \\
\text { not evolved enough to predict everything observed in animals. But things are } \\
\text { progressing. I hope that in the not so distant future we will be able to develop } \\
\text { new drugs or other kinds of health care products without resorting to animal } \\
\text { experimentation or if still necessary resorting to its use in a drastically reduced } \\
\text { number of animals. }\end{array}$ & $\begin{array}{l}\text { (B2) I believe that some experimental models } \\
\text { used in animals can be replaced by models in } \\
\text { humans. However, some studies, especially } \\
\text { those involving investigation of drugs } \\
\text { mechanisms of action or other therapeutic } \\
\text { resources, need animal experimentation. }\end{array}$ \\
\hline $\begin{array}{l}\text { (A3) I am actively involved in seeking alternatives to animal experimentation } \\
\text { (e.g. in silico techniques). The hope is that in the future such methods } \\
\text { will be able to replace animal studies completely. However, at present the } \\
\text { techniques are not good enough and it will take a long time for alternatives } \\
\text { to be established. } \\
\text { It is difficult to answer the above questions accurately as expressions such as } \\
\text { "medium term" are not defined. Animal experimentation may be "essential } \\
\text { to science" now but may not be in the future. }\end{array}$ & $\begin{array}{l}\text { (B3) Animal experimentation is essential to } \\
\text { research. }\end{array}$ \\
\hline $\begin{array}{l}\text { (A4) I was often unhappy with the default answers that did not provide } \\
\text { something like "it depends!". For someone who has been actively and } \\
\text { successfully replacing animal tests in the past } 20 \text { years, the default answers } \\
\text { were not really suitable. }\end{array}$ & $\begin{array}{l}\text { (B4) There is an excess of animal research with } \\
\text { doubtful scientific value and that disrespects } \\
\text { ethics involving animals. I think there is a lot } \\
\text { of animal sacrifice for little benefit. }\end{array}$ \\
\hline
\end{tabular}


perimentation, as A2 affirms: “(...) things are progressing. I hope that in the not so distant future we will be able to develop new drugs or other kinds of health care products without resorting to animal experimentation (... )", and A1: "Non-animal and animal testing should go hand in hand with the purpose of phasing out animal testing". As A3 affirms: "Animal experimentation may be "essential to science' now but may not be in the future".

\section{DISCUSSION}

\section{Two different thought collectives and styles}

Figures 3 and 4 show the general behavior of innovative and traditional entries identified in both groups, and suggest that these groups have opposite stances in relation to animal experimentation.

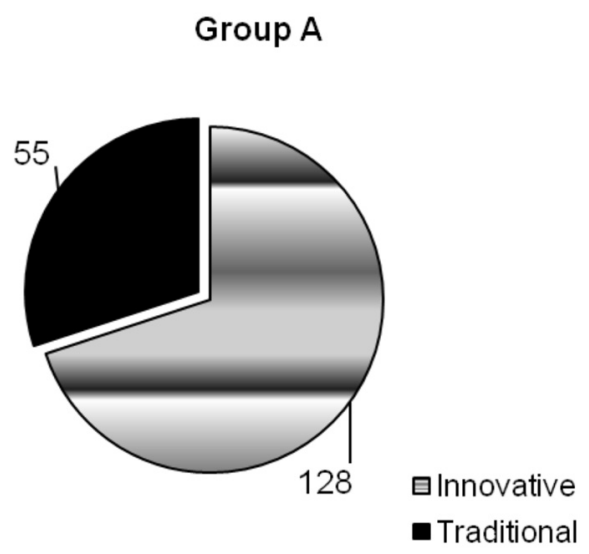

FIGURE 3 - Total entries in Group A.

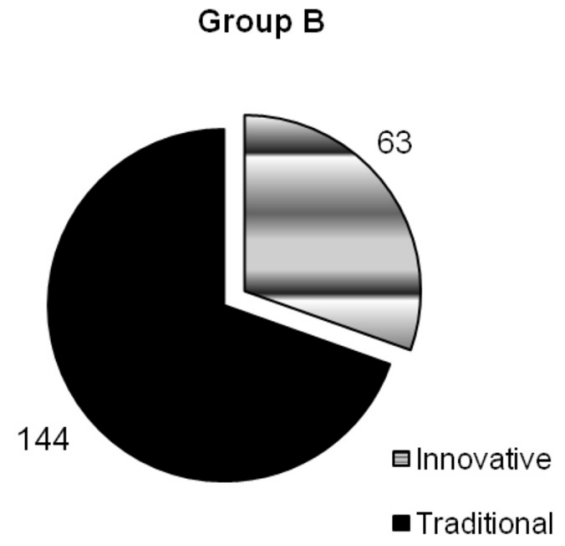

FIGURE 4 - Total entries in Group B.

Given the degree of importance that the method of animal experimentation seems to raise in a lot of literature and verified in the introduction of this article, we can conclude that this method sustains a seemingly hegemonic thought collective within the scientific community. This article suggests that other collectives may be identified, whose positioning and practices seem to point to a different and opposite scientific behavior.

In this sense, the different productions and justifications seem to characterize what Fleck called complication, which leads us to believe that the problem of research on safety of techniques and substances applied for advance in human health, is being conceived and treated differently by part of the scientific community.

The tendency to replace methods in research has previously been recognized by some Brazilian researchers, and reflects the stance found in Group A.

It can be inferred that the use of alternative methods follows an international tendency, toward understanding the biological phenomena and, mainly, the search for reliable instruments that can substitute the use of animal models as much as possible without damaging the demonstrative results and the research (Mezadri et al., 2004)

In Brazil, however, the established stance does not seem to reflect this tendency. In spite of the affirmation of Morales (2008) that the search for replacement methodologies needs to be one of the objectives of modern science, "few advances were obtained in order to exclude this practice [of animal experimentation] in scientific research". As Cazarin et al. (2004) say:

The discussion on the use of animals in research, the intention to reduce their use and the development of new methodologies remains incipient in the Brazilian reality (p.296).

As Graph 2 suggests, there is little dedication on the part of the sampled researchers in Group B toward finding new methodologies. The traditional posture seems to remain pessimistic or skeptical in relation to the world tendency. Morales (2008) says that there are very few "cases where substitute methods are capable of replacing the use of animals", and Dr. Ekaterina Rivera believes that "alternative methods demand a long time, a lot of money and a lot of patience to be developed" (Cerqueira, 2008). However, Dr. Carlos Zanetti, working with rabies virus isolation through in vitro culture, commented that numerous alternatives have existed in Europe for decades, but are not well accepted in Brazil because often the animal house structure is already in operation and, seemingly, it is simpler to use this than to set up 
a new structure for the cultivation of cellular lineages (Cerqueira, 2008)

According to the researcher Octávio Presgrave, although several research groups are working on the perspective of replacing animal models in Brazil, they do so in an isolated way and without funding policies (São Paulo, 2009). The funding question is crucial in research, because it drives the research behaviors in different fields. This can explain the entries in Question 13, for option D in Group B, and for option A in Group A (Graph 2). Simply to illustrate, a joint announcement of an initiative by the European Union and COLIPA (The European Cosmetics Association) was launched in 2009 to stimulate research with replacement methods in systemic toxicity, to the value of $€ 50$ million (EUROPE, 2009). In the same year the Dr. Hadwen Trust offered a grant to the value of $£ 400,000$ for research promoting replacement methods in tissue engineering and advanced cell culture techniques, computer modeling, disease models, research into Parkinson's and Alzheimer's disease, infectious diseases, cancer and cardiovascular research, replacement of animal antibodies and replacements for animal serum in research or methods to promote the replacement of animal serum (Dr Hadwen Trust for Humane Research, 2010).

While the state-of-the-art scenario seems to indicate this path, the historical perception of animal experimentation also seems to be divided, as evidenced by both groups in Question 4. The main literature in Brazil serves to illustrate one historical conception (and understanding) of an indispensable role attributed to animal experimentation in advancing human health. Historical understandings that counter this importance, however, can be found widely in internationa ${ }^{11}$ and national publications ${ }^{12}$.

As Dr. Beddow Bayly (1961) comments:

The paramount need for a clear and documented account of past achievements arises from the prevalent custom of those medical authorities who set out to support and defend the practice of experimenting on living animals so far, to distort historical facts so as to create the impression in the mind of the public that every single medical diagnosis and treatment had depended for its discovery and application on vivisection... Happily, even the briefest perusal of the available evidence shows the falsity of these claims and provides historical proof of the supreme value of clinical observation and experiment when contrasted with the doubtful and often misleading practice of animal experimentation (p. 18-19, apud Greek \& Greek, 2000)

This statement and the above-mentioned considerations reinforce, when analyzed together with the obtained data, the view that there are possibly two thought collectives operating in consonance on the same problem, and in dissonance on their practices and current research concepts, as well as in terms of their respective historical judgments. A future study involving a broader sample and/ or which embraces qualitative aspects, however, would be necessary for more precise identification of the thought collectives presented here, and a possible process of instauration of the non-hegemonic collective.

\section{ACKNOWLEDGEMENTS}

The author would like to thank the Brazilian Federal Agency for Support and Evaluation of Graduate Education (CAPES).

\section{REFERENCES}

ANDRADE, A.; PINTO, S.C.; OLIVEIRA, R.S. Animais de laboratório: criação e experimentação. Rio de Janeiro: Editora FioCruz, 2002. 387 p.

BAYLY, M.B. Clinical medical discoveries. London: National Anti-Vivisection Society, 1961. Apud GREEK, R.; GREEK, J.S. Sacred Cows and Golden Geese: the human cost of experiments on animals. London: Continuum, 2000. 224 p.

CAZARIN, K.C.C.; CORRÊA, C.L.; ZAMBRONE, F.A.D. Redução, refinamento e substituição do uso de animais em estudos toxicológicos: uma abordagem atual. Rev. Br. Ciênc. Farm., v.40, n.3, p.289-299, 2004.

CERQUEIRA, N. Métodos alternativos são poucos e não substituem totalmente o uso de animais. Cienc. Cult., v.60, n.2., p.47-49, 2008.

\footnotetext{
11To mention a few: Victims of science : the use of animals in research (Ryder, 1975); Man and Mouse: Animals in Medical Research (Paton, 1984); Of Mice, Models, and Men: A Critical Evaluation of Animal Research (Rowan, 1984); The Cruel Deception: Use of Animals in Medical Research (Sharpe, 1988); Animal Experimentation: The Consensus Changes (Langley, 1990); Animal Experimentation and Human Medicine (Frazza, 1995); Animal experimentation: a harvest of shame (Fadali, 1996); Vivisection Unveiled: An Expose of the Medical Futility of Animal Experimentation (Page, 1998); Sacred Cows and Golden Geese (Greek, Greek, 2000);

${ }^{12}$ See: A verdadeira face da experimentação animal (Greif, Tréz, 2000); Ética e experimentação animal (Felipe, 2007)
} 
D'ACÂMPORA, A.J.; ROSSI, L.F.; BINS ELY, J.; VASCONCELLOS, Z.A. Is animal experimentation fundamental? Acta Cir. Bras., v.24, n.5, p.423-425, 2009.

DELIZOICOV, D.; CASTILHO, N.; CUTOLO, L.R.A.; DA ROS, M.A.; LIMA, A.M.C. Sociogênese do conhecimento e pesquisa em ensino: contribuições a partir do referencial Fleckiano. Cad. Cat. Ens. Fís., v.19, núm. Espec., p.50-66, 2002

DR HADWEN TRUST FOR HUMANE RESEARCH. New grant application invited now. Available at: http://www. drhadwentrust.org/smartweb/research-and-funding/ research-and-funding. Accessed on: $3^{\text {rd }}$ jun. 2010.

EUROPA Press Releases. The European Commission and the cosmetic industry match research funds to develop alternative solutions to animal testing. Available at: http:// europa.eu/rapid/pressReleasesAction.do?reference=IP/09/ $1262 \&$ format $=$ HTML\&aged $=0$ \&language $=$ EN\&guiLangu age $=$ en. Accessed on: $3^{\text {rd }}$ Jun. 2010.

MELLO, L.E. A ciência pode abrir mão de fazer experiências com animais? Uma necessidade científica básica. Folha de São Paulo, 10 nov. 2007. Seção Debate. p.3.

FREITAS, H.; OLIVEIRA, M.; SACCOL, A.Z; MOSCAROLA, J. O método de pesquisa survey. Rev. Adm. USP, v.35, n.3, p.105-112, 2000.

FRENCH, R. Dissection and vivisection in the european renaissance. Aldershot: Ashgate Publishing. 1999. 289 p.

GONÇALVES, F.P.; MARQUES, C.A.; DELIZOICOV, D. O desenvolvimento profissional dos formadores de professores de Química: contribuições epistemológicas. Rev. Br. Pesqu. Educ. Ciênc., v.7, n. 3, 2007.

GUERRA, R.F. Sobre o uso de Animais na Investigação Científica. Impulso, Piracicaba,15(36): 87-102, 2004

LIMA, W.T. Entendimento humano da experimentação animal. Cienc. Cult. v.60, n.2., p.26-27, 2008.

MEZADRI, T.J.; TOMÁZ, V.A.; AMARAL, V.L.L. Animais de laboratório: cuidados na iniciação experimental. Florianópolis: Editora da UFSC, 2004. 154 p.

MARKUS, R.P. Legal, legítimo e ético - avanços da ciência busca do conhecimento. Cienc. Cult., v.60, n.2., p.24-25, 2008 .
MARQUES, R.G.; MIRANDA, M.L.; CAETANO, C.E.R.; BIONDO-SIMÕES, M.L.P. Rumo à regulamentação da utilização de animais no ensino e na pesquisa científica no Brasil. Acta Cir. Bras., v.20, n.3, p.262-267, 2005.

MARQUES, R.G.; MORALES, M.M.; PETROIANU, A. Brazilian law for scientific use of animals. Acta Cir. Bras. v.24, n.1, p.69-74, 2009.

MORALES, M. Métodos alternativos à utilização de animais em pesquisa científica: mito ou realidade? Cienc. Cult. v.60, n.2., p.33-36, 2008

NASCIMENTO, T.G. Contribuições da análise do discurso e da epistemologia de Fleck para a compreensão da divulgação científica e sua introdução em aulas de ciências. Rev. Ensaio, v.7, n.2, p.1-18, 2005.

PETROIANU, A. Aspectos éticos na pesquisa em animais. Acta Cir. Bras., v.11, n.3, p.157-164, 1996.

PFUETZENREITER, M.R. A epistemologia de Ludwik Fleck como referencial para a pesquisa no ensino na área de saúde. Ciênc. Educ., v.8, n.2, p.147-159, 2002.

QUEIRÓS, W. P.; NARDI, R. Um Panorama da Epistemologia de Ludwik Fleck na Pesquisa em Ensino de Ciências. In: ZIRMMERMANN, E.; GARCIA, N. M. D.; SILVA, C. C.; MARTINS, A. F. P. Anais do XI Encontro de Pesquisa em Ensino de Física. Curitiba, PR: SBF. p.1-11, 2008.

REZENDE, A.H.; PELUZIO, M.C.G.; SABARENSE, C.M. Experimentação animal: ética e legislação brasileira. Rev. Nutr., v.21, n.2, p.237-242, 2008

SÃO PAULO. (Estado) Secretaria de Ensino Superior. Experimentação animal é tema de debate já no início da SBPC. Available at: http://www.ensinosuperior.sp.gov.br/ sis/lenoticia.php?id=1069. Accessed on: $3^{\text {rd }}$ Jun. 2010.

SCHNAIDER, T.B.; SOUZA, C. Aspectos éticos da experimentação animal. Rev. Bras. Anestesiol., v.53, n.2., p.278-285, 2003.

Received for publication on $05^{\text {th }}$ Jan 2010. Accepted for publication on $15^{\text {th }}$ June 2010 . 